九州大学学術情報リポジトリ

Kyushu University Institutional Repository

\title{
Energy Management and Heat Storage for Solar Adsorption Cooling
}

\section{Rouf, Rifat Ara}

School of Engineering and Computer Science, Independent University, Bangladesh

Khan, M. A. Hakim

Department of Mathematics, Bangladesh University of Engineering and Technology

Kabir, K. M. Ariful

Department of Mathematics, Bangladesh University of Engineering and Technology

Saha, Bidyut Baran

International Institute for Carbon-Neutral Energy Research (WPI-I2CNER), Kyushu University I Kyushu University Program for Leading Graduate School, Green Asia Education Center

https://doi.org/10.5109/1800866

出版情報: Evergreen. 3 (2)，pp.1-10，2016-09. Green Asia Education Center バージョン：

権利関係 : 


\title{
E nergy M anagement and H eat Storage for Solar Adsorption C ooling
}

\author{
Rifat Ara Rouf ${ }^{1, *}$, M. A. Hakim Khan ${ }^{2}, K$. M. A riful Kabir ${ }^{2}$, \\ Bidyut Baran Saha ${ }^{3,4}$ \\ ${ }^{1}$ School of Engineering and Computer Science, Independent U niversity, B angladesh, D haka, B angladesh \\ ${ }^{2}$ Department of $M$ athematics, $B$ angladesh U niversity of Engineering and Technology, D haka, B angladesh \\ ${ }^{3}$ International Institute for Carbon-N eutral Energy Research (W PI-I2CNER), K yushu University, 744 M otooka, \\ Nishi-ku, Fukuoka 819-0395, Japan \\ ${ }^{4}$ K yushu U niversity Program for L eading Graduate School, Green A sia E ducation Center, K asuga-koen 6-1, \\ Kasuga-shi, Fukuoka 816-8580, J apan
}

*A uthor to whom correspondence should be addressed,

E-mail: rifatara@iub.edu.bd

(Received J une 15, 2016; accepted A ugust 22, 2016)

\begin{abstract}
A solar heat driven cooling system utilizes abandoned solar radiation, plays an important role in preservation of primary energy, prevents sound pollution and chlorofluorocarbon (CFC) /hydro-chlorofluorocarbon (HCFC) free environment. Other than the installation and commissioning cost, the running cost of this system can be reduced to its bare minimum by maximum exploitation of the collected solar energy. This article points out a way how collected heat energy can be properly utilized to run a conventional two bed solar adsorption cooling system to produce optimum cooling energy ensuring prolonged coverage. Increased solar thermal units can enhance heat collection up to $864.1006 \mathrm{MJ} / 75.68 \mathrm{~m}^{2}$ of collector area. Enlarged storage tank provides backup for longer working hours, 14 hours a day. On the other hand, a smart choice of operating conditions can ensure a higher cooling capacity of $16.1 \mathrm{~kW} / 2.197 \mathrm{~m}^{3}$ heat storage tank at peak hours and a comfortable, steady cooling effect over a relatively longer duration. Proper management of collected energy can turn out to be an economic gain factor in a developing country like Bangladesh. It could save roughly BDT $9324 \approx \$ 116.55 /$ year for only 1 RT space cooling purpose. Moreover, it lowers $\mathrm{CO}_{2}$ emission and preserves primary energy and electricity.
\end{abstract}

K eywords: solar heat, adsorption chiller, energy management, green energy.

\section{Introduction}

At present, in the field of energy systems the study in various energy conversion systems mainly heat pumps, sorption systems, energy conversion and storage devices are in the top priority. Adsorption refrigeration and air conditioning cycles have earned considerable attention due to its ability to utilize low temperature heat source and for the environmental aspects as it uses environment friendly ref rigerants. The advantage and development of adsorption cycle have been widely studied by Meunier [1]. Later, researchers have made development to adsorption technology. In this respect, some have considered the improvement of the coefficient of performance (COP values) while the others focused on the system cooling capacity. A dsorption technology had also been utilized for desalination and water treatment purposes [2-5]. Advanced cascaded cycle [6], thermal wave cycles [7] have been introduced for the enhancement of COP values. While mass recovery cycle [8-9] is for improvement of system cooling capacity. A dvanced multiple-bed system [10], such as three-stage [11] and two-stage [12] cycles could be effective for utilization of low temperature heat source. Uddin et al.

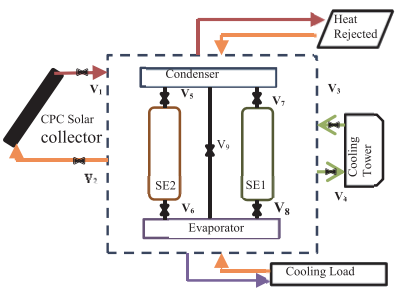

a)

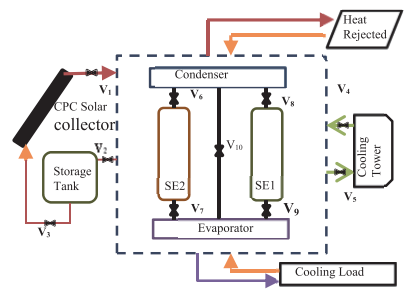

b)
Fig. 1: Schematic diagram of solar adsorption cooling system a) with direct solar coupling and b) system with heat storage 
[13] published thermodynamic analysis of adsorption cooling cycle for Ethanol surface treated Maxsorb III pairs.

Adsorption technology with solar coupling could be one of the attractive and alternative energy source to produce necessary cooling instead of conventional energy source. Sakuda and Suzuki [14], Leite and Daguenet [15], Boubarkri [16] studied solar ice making with adsorption technology coupled with solar heat collectors. Yang and Sumanthy [17] first exploited the lumped parameter model for two beds adsorption cycle driven by solar heat. Later, Clausse et al. [18] investigated the performances of a small adsorption unit for residential air conditioning in summer and heating during the winter period for the climatic condition of Orly, France. And Zhang et al. [19] investigated the operating characteristics of silica gel-water pair as adsorbent/ adsorbate utilizing solar powered adsorption cooling system. Recently A lam et al [20] investigated the performances of solar collector driven adsorption cooling system under the climatic condition of Tokyo, Japan. A similar study has been carried out by Rouf et al [21] for the climatic condition of Dhaka, Bangladesh. Later, effect of the operating conditions for a two bed basic adsorption cycle with silica gel-water pair powered by solar heat has been investigated [22].

However, this system has a vital setback. Intermittent solar energy cannot provide tangible support to run such a system unhampered. Also even if solar radiation is available for few sunny days, the system can work only for a limited time, as long as there is enough radiation available to provide sufficient thermal heat to run the chiller. Various options have been investigated to work out this problem such as natural gas or electric vapor compression chiller, thermal storage (cold or hot); a mix between these options. F. M eunier [23] recommend, a conventional electric vapor compression chiller backed by sorption unit when solar energy is present. A mmar et. al. [24] investigated analytically the performance of different adsorbent for tubular adsorber for solar powered adsorption refrigeration system in sub-Sahara region of Algeria. This paper addresses the option of adsorption solar air conditioning with hot thermal storage. This problem is same as liquid absorption.

A lam et al. [25] discussed utilization of heat storage as a backup heat supplier after sunset. Rout et al. [26] compared the longer working capacity of the chiller with heat storage and that of a chiller with direct solar coupling. Kim et al. [27] studied economic aspects of a solar hot water plant. Present study investigates a standard size of the heat storage in need of maximum heat collection and preservation. And thus calculates optimum cooling capacity with base run conditions. For intermittent heat source like solar radiation, choice of erratic cycle time can play an interesting role and increase cooling capacity of the system. Additionally, a controlled flow of chilled water can ensure a steady cooling effect to the end user. The investigation is conducted on a two bed adsorption cooling system which is run by solar heat, with silica gel-water pair as adsorbent/ adsorbate under the climatic condition of $D$ haka. The place is located in the northern hemisphere at $23^{\circ} 46^{\prime} \mathrm{N}$ (latitude), and $90^{\circ} 23^{\prime} \mathrm{E}$ (longitude).

\section{System description}

A conventional basic adsorption chiller consisting two adsorbent beds, one condenser and one evaporator has been considered. The chiller configuration is same as Saha et al. [28] where silica gel-water pair has been utilized as adsorbent/adsorbate pair. The principle of basic adsorption cycle is available in this literature. The operating conditions are presented in Table 1. Solar collector data, compound parabolic concentrator CPC1509 manufactured by Ritter Solar, are utilized as heat source for the chiller. Solar radiation data has been supported by renewable energy research center (RERC) of University of Dhaka. The working principle of the present chiller is available in [25]. The schematic diagram of the chiller is given in Fig. 1.

The position of SE 1 and SE2 (adsorption beds) during the different mode in a full cycle is represented in table 2. For the system with heat storage, the heat transfer fluid (water) is heated in the solar collector and transported to the desorber. Desorber gains heat and the outflow of this hot water from the desorber is collected in the storage tank. Storage tank supplies water to the collector where it gains heat and complete the cycle. In this article different dimension of the reserve tank has been investigated. Specification of the reserve tank is given in table 3.

Table 1. Design and the operating conditions used in the simulation

\begin{tabular}{|c|c|c|}
\hline Symbol & Description & Value \\
\hline$A_{\text {bed }}$ & Adsorbent bed heat transfer area & $2.46 \mathrm{~m}^{2}$ \\
\hline$A_{c o n}$ & Condenser heat transfer area & $3.73 \mathrm{~m}^{2}$ \\
\hline$A_{c r}$ & Each collector area & $1.72 \mathrm{~m}^{2}$ \\
\hline$A_{\mathrm{eva}}$ & Evaporator heat transfer area & $1.91 \mathrm{~m}^{2}$ \\
\hline $\mathrm{C}_{\mathrm{p}, \mathrm{M}(\mathrm{Al})}$ & Specific heat of aluminum (A I) & $905 \mathrm{~J} / \mathrm{kg} \cdot \mathrm{K}$ \\
\hline $\mathrm{C}_{\mathrm{p}, \mathrm{M}(\mathrm{Cu})}$ & Specific heat of copper (Cu) & $386 \mathrm{~J} / \mathrm{kg} . \mathrm{K}$ \\
\hline $\mathrm{C}_{\mathrm{p}, \mathrm{Si}}$ & Specific heat of silica gel & $924 \mathrm{~J} / \mathrm{kg} . \mathrm{K}$ \\
\hline $\mathrm{C}_{\mathrm{p}, \mathrm{W}, \mathrm{l}}$ & Specific heat of water (liquid phase) & $4180 \mathrm{~kJ} / \mathrm{kg} . \mathrm{K}$ \\
\hline
\end{tabular}




\begin{tabular}{|c|c|c|}
\hline$C_{p, w, v}$ & Specific heat of water (vapor phase) & $1890 \mathrm{~J} / \mathrm{kg} . \mathrm{K}$ \\
\hline$D_{s 0}$ & Diffusion coefficient & $2.54 \mathrm{~cm}^{2} / \mathrm{s}$ \\
\hline $\mathrm{Ea}$ & A ctivation energy & $2330 \mathrm{~kJ} / \mathrm{kg}$ \\
\hline $\mathrm{i}$ & N umber of pipe in each collector & 9 \\
\hline $\mathrm{L}$ & L atent heat of vaporization (water) & $2600 \mathrm{~kJ} / \mathrm{kg}$ \\
\hline$\dot{\mathrm{m}}_{\mathrm{f}, \mathrm{cool}}$ & Cooling water flow rate to adsorber & $1.3 \mathrm{~kg} / \mathrm{s}$ \\
\hline$\dot{m}_{\mathrm{f}, \mathrm{con}}$ & Cold water flow rate to condenser & $1.3 \mathrm{~kg} / \mathrm{s}$ \\
\hline$\dot{\mathrm{m}}_{\mathrm{f}, \mathrm{hot}}$ & $\begin{array}{c}\text { Total mass flow rate to CPC panel } \\
\text { or to desorber }\end{array}$ & $1.3 \mathrm{~kg} / \mathrm{s}$ \\
\hline Q st & Heat of adsorption (silica gel bed) & $2810 \mathrm{~kJ} / \mathrm{kg}$ \\
\hline R & Water gas constant & $46.2 \mathrm{~kJ} / \mathrm{kg} . \mathrm{K}$ \\
\hline $\mathrm{R}_{\mathrm{p}}$ & Particle diameter (Silica gel) & $0.035 \mathrm{~cm}$ \\
\hline$U_{\text {bed }}$ & Heat transfer coefficient of each bed & $\begin{array}{r}1724.14 \\
\mathrm{~W} / \mathrm{m}^{2} \mathrm{~K}\end{array}$ \\
\hline$U_{\text {con }}$ & Condenser heat transfer coefficient & $\begin{array}{l}4115.23 \\
\mathrm{~W} / \mathrm{m}^{2} \mathrm{~K}\end{array}$ \\
\hline$U_{\text {eva }}$ & Evaporator heat transfer coefficient & $\begin{array}{l}2557.54 \\
W / m^{2} K\end{array}$ \\
\hline Wcon,w & $\begin{array}{c}\text { Condenser refrigerant (water) inside } \\
\text { condenser }\end{array}$ & $0.0 \mathrm{~kg}$ \\
\hline$W_{\text {eva,w }}$ & $\begin{array}{l}\text { Liquid refrigerant (water) inside } \\
\text { evaporator initially }\end{array}$ & $50 \mathrm{~kg}$ \\
\hline$W_{\mathrm{si}}$ & Weight of silica gel in each bed & $47 \mathrm{~kg}$ \\
\hline
\end{tabular}

\section{Mathematical modeling}

A lumped parameter model is exploited to investigate the performance of the cycle. It is assumed that the temperature, pressure and concentration throughout the adsorbent bed are uniform. Based on these assumptions the energy balance equation of the adsorbent bed, working as desorber or adsorber is as follows:

$$
\begin{aligned}
& \frac{d}{d t}\left\{\left(W_{M} C_{p M}+W_{s} C_{s}+W_{S} q C_{W}\right) T_{\text {bed }}\right\}=Q s t \cdot W_{S} \frac{d q}{d t} \\
& \quad+\delta \cdot W_{S} C_{p, w, v} \frac{d q}{d t}\left(T_{\text {eva }}-T_{\text {bed }}\right)+\dot{m}_{f} C_{f}\left(T_{\text {bed, in }}-T_{\text {bed, out }}\right) \\
& + \text { UlossAS bed }\left(T_{\text {am }}-T_{\text {bed }}\right)
\end{aligned}
$$

$T_{\text {bed, out }}=T_{\text {bed }}+\left(T_{\text {bed, in }}-T_{\text {bed }}\right)$ EXP $\quad\left(-U A_{\text {bed }} / \mathrm{m}_{f} C_{f}\right)$

where, $\delta$ equals to zero or one depending on whether adsorbent bed is working as desorber or adsorber. The energy balance for the condenser is represented by:

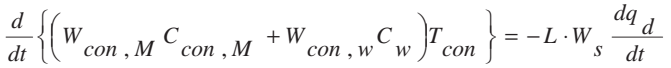

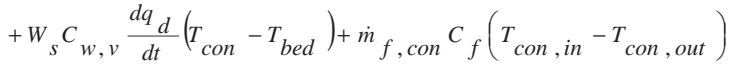

$$
\begin{aligned}
& T_{\text {con, out }}=T_{\text {con }}+\left(T_{\text {con, in }}-T_{\text {con }}\right) \operatorname{EXP}\left(-U A_{\text {con }} / \dot{m}_{f, \text { con }} C_{f}\right)
\end{aligned}
$$

Energy balance for the evaporator is represented by:

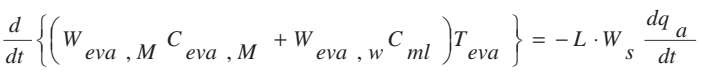

$$
\begin{aligned}
& +W_{s} C_{w, l} \frac{d q}{d t}\left(T_{\text {eva }}-T_{\text {con }}\right)+m_{f \text {, chill }} C_{f}\left(T_{\text {chill }} \text {, in }{ }^{-T_{\text {chill }} \text {, out }}\right) \\
& T_{\text {chill , out }}=T_{\text {eva }}+\left(T_{\text {chill, in }}-T_{\text {eva }}\right) \operatorname{EXP}\left(-U A_{\text {eva }} / \dot{m}_{f, \text { chill }} C_{f}\right)
\end{aligned}
$$

Table 2: Performance of SE 1 and SE2 during different mode of a cycle

\begin{tabular}{|c|c|c|c|c|c|}
\hline cycle & $\begin{array}{c}\text { M ode } \\
->\end{array}$ & $\begin{array}{c}\text { Pre- } \\
\text { cool }\end{array}$ & $\begin{array}{c}\text { A dsor } \\
\text { ption/ } \\
\text { evapor } \\
\text { ation }\end{array}$ & $\begin{array}{c}\text { Pre- } \\
\text { heat }\end{array}$ & $\begin{array}{c}\text { Desorp } \\
\text { tion/ } \\
\text { conden } \\
\text { sation }\end{array}$ \\
\hline $1^{\text {st }}$ half & A & SE1 & --- & SE2 & --- \\
\hline $1^{\text {st }}$ half & B & --- & SE1 & --- & SE2 \\
\hline $2^{\text {nd }}$ half & C & SE2 & --- & SE1 & --- \\
\hline $2^{\text {nd }}$ half & D & --- & SE2 & --- & SE1 \\
\hline
\end{tabular}


Table3. Design and operating conditions of the reserve tank used in the simulation

\begin{tabular}{|c|c|l|}
\hline Symbol & Description & \multicolumn{1}{c|}{ Value } \\
\hline $\mathrm{L}$ & Dimension of the tank & $0.7 / 1 / 1.3 \mathrm{~m}$ \\
\hline $\mathrm{W}_{\mathrm{tv}}$ & Volume of the tank & $\mathrm{L}^{3} \mathrm{~m}^{3}$ \\
\hline $\mathrm{W}_{\mathrm{wt}}$ & Weight of water in reserve & $\mathrm{W}_{\mathrm{tv}} \times 1000-10 \mathrm{~kg}$ \\
\hline $\mathrm{U}_{\mathrm{tloss}}$ & Reserve tank heat transfer loss & $0.5 \mathrm{~W} / \mathrm{m}^{2} \mathrm{~K}$ \\
\hline $\mathrm{A}_{\mathrm{wt}}$ & Reserve tank outer surface & $6 \times \mathrm{L}^{2} \mathrm{~m}^{2}$ \\
\hline $\mathrm{W}_{\mathrm{tm}}$ & area & \\
\hline
\end{tabular}

The mass balance of the refrigerant inside the

Evaporator is expressed as:

$$
\frac{d W_{\text {eva }, w}}{d t}=-W_{s}\left(\frac{d q a}{d t}+\frac{d q d}{d t}\right)
$$

Adsorption rate of RD type silica gel-water pair is estimated by LDF model as;

$$
\frac{d q}{d t}=k_{s} a_{p}\left(q^{*}-q\right)
$$

Where, $k_{s} a_{p}$ is the overall mass transfer coefficient of the adsorbent/adsorbate pair and can be represented as;

$$
k_{s} a_{p}=\left(15 * D_{s}\right) /\left(R_{p}\right)^{2}
$$

where, $R_{p}$ is the adsorbent particle radius, $D_{s}$ is the surface diffusivity and can be expressed by Arrhenius equation as

$$
\mathrm{D}_{\mathrm{s}}=\mathrm{D}_{\mathrm{s} 0} * \exp \left(-\mathrm{E}_{\mathrm{a}} / \mathrm{RT}\right)
$$

the modified Freundlich (S-B-K) equation is used to present the adsorption isotherms of $\mathrm{RD}$ type silica gel-water pair as

$$
q^{*}=A \cdot \cdot\left(P_{s}\left(T_{v}\right) / P_{s}\left(T_{b}\right)\right)^{B B}
$$

where,

$$
A A=A_{0}+A_{1} T+A_{2} T^{2}+A_{3} T^{3}
$$$$
\text { and } \quad B B=B_{0}+B_{1} T+B_{2} T^{2}+B_{3} T^{3} \text {. }
$$

The numerical values $A_{i}$ 's and $B_{i}$ 's are given in table 4.

Different numbers of collectors are combined in a panel. The heat transfer fluid is equally distributed to all the collectors. Each collector has nine pipes; water enters through the first pipe and the outlet of the first pipe

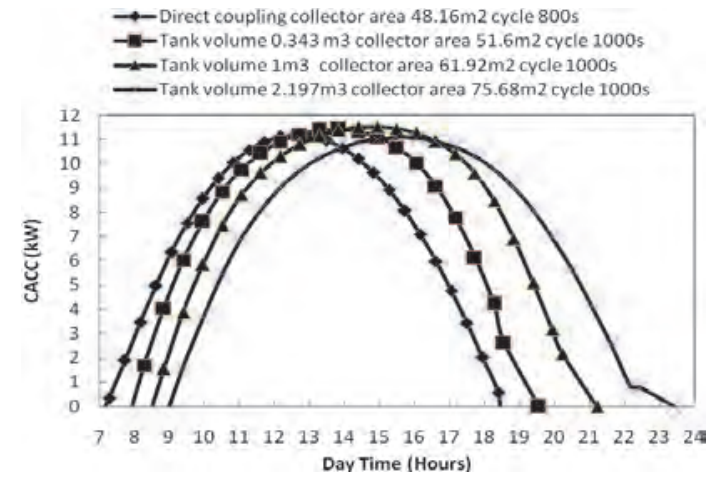

Fig. 2. Comparative cyclic average cooling capacity of the chiller with direct solar coupling and different dimension of storage tank with cycle time

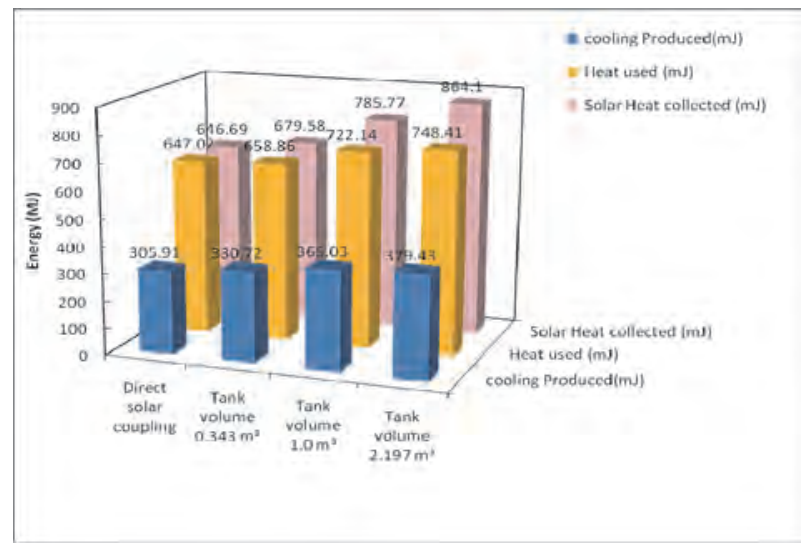

Fig. 3. Cooling load, heat in used and net heat collected of the chiller for different cases

flows into the next pipe. Thus, the outlet of the ninth pipe of each collector combines together and enters into the desorber. Hence, the temperature of the heat transfer fluid in each pipe is calculated separately for all the collectors. The energy balance of each collector can be expressed as:

$$
\begin{gathered}
W_{c p, i} C_{c r} \frac{d T}{c r, i} \frac{d t}{d t}=\gamma\left\{\eta_{i} A_{c r, i} I+\dot{m}_{f, c r} C_{f}\left(T_{c r, i, i n}-T_{c r, i, o u t}\right)\right\}+(1-\gamma)_{\text {loss }} A_{c r i}\left(T_{a m}-T_{c r, i}\right) \\
T_{c r, i, o u t}=T_{c r, i}+\left(T_{c r, i, i n}-T_{c r, i}\right) \operatorname{EXP}\left(U_{c p, i} A_{c p, i} / \dot{m}_{f, c r} C_{f}\right)
\end{gathered}
$$

where, $i=1, \ldots, 9 \cdot \gamma$ is either 1 or 0 depending on whether it is daytime or nighttime.

The energy balance for the reserve tank can be ex pressed as:

$$
\frac{d}{d t}\left\{\left(w_{t m} C_{t m}+W_{w t} C_{w}\right) T_{w t}\right\}=\dot{m}_{w} C_{w}\left(T_{\text {bed, out }}-T_{w t}\right)+U_{\text {tloss }} A S_{t t}\left(T_{\text {am }}-T_{w t}\right)
$$

where, $\quad T_{c r, i, \text { out }}=T_{c r, i+1, \text { in }} \quad T_{c r, 9, \text { out }}=T_{\text {bed, in }}$

and $\quad \mathrm{T}_{\text {bed,out }}=\mathrm{T}_{\mathrm{wt}, \text { in }}$

The bed, evaporator and condenser energy balances and concentration in beds are calculated according to Saha et al. [29]. 
Table 4. Coefficients $A_{i}$ and $B_{i}$

\begin{tabular}{|c|l|l|l|l|}
\hline $\begin{array}{c}\text { Coefficient } \\
\text { (i) }\end{array}$ & 0 & 1 & 2 & 3 \\
\hline $\mathbf{A}_{\mathbf{i}}$ & -6.5314 & $0.72452 \times 10^{-1}$ & $-0.23951 \times 10^{-3}$ & $0.25493 \times 10^{-6}$ \\
\hline$B_{i}$ & -15.587 & 0.15915 & $-0.50612 \times 10^{-3}$ & $0.5329 \times 10^{-1}$ \\
\hline
\end{tabular}

The collector efficiency equation is:

$$
\eta=0.64-0.89\left(\frac{\mathrm{T}_{\mathrm{f}}-\mathrm{T}_{\mathrm{am}}}{\mathrm{I}}\right)-0.001\left(\frac{\mathrm{T}_{\mathrm{f}}-\mathrm{T}_{\mathrm{am}}}{\mathrm{I}}\right)^{2}
$$

A nd solar radiation equation is considered to be same as Alam et al. [20]. The cyclic average cooling capacity (CACC) is calculated by the equation:

$$
C A C C=m_{\text {chill }} C_{\text {chill, } f}\left(\int_{\text {beginorycycteime }}^{\text {endofycletime }}\left(T_{\text {chill, in }}-T_{\text {chill, out }}\right) d t\right) / t_{\text {cycle }}
$$

The cycle COP (coefficient of performance) and net solarCOP ( $\left.\mathrm{COP}_{\text {solar,net }}\right)$ are calculated respectively by the equations:

$$
\begin{aligned}
& \operatorname{COP} \text { cycle }=\frac{\int_{\text {beginofycletime }}^{\text {endofcycletime }} \dot{m}_{\text {chill }} C_{\text {chill, } f}\left(T_{\text {chill, in }}-T_{\text {chill out }}\right) d t}{\int_{\text {beginofcycletime }} \dot{m}_{f} C_{f}\left(T_{d, \text { in }}-T_{d, \text { out }}\right) d t} \\
& \operatorname{COP}_{\text {solar, net }}=\frac{\int_{\text {sunrisetime }}^{\text {chiller stoptime }} \dot{m}_{\text {chill }} C_{\text {chill }}\left(T_{\text {chill, in }}-T_{\text {chill, out }}\right) d t}{\int_{\text {sunrisetime }}^{\text {chiller stoptime }} n \cdot A_{\text {cr }} I d t}
\end{aligned}
$$

where, $I$ is the solar irradiance, $A_{c r}$ is each collector area and $n$ is number of collectors. Therefore, the total cooling energy produced in a full day by the chiller can be expressed as:

$$
Q_{r}=\int_{\text {chill lerstartingtime }}^{\text {chillerstopingtime }} \dot{m}_{\text {chill }} C_{\text {chill }}\left(T_{\text {chill, in }}-T_{\text {chill, out }}\right) d t \text {. }
$$

Similarly, total heat energy used in cooling production $Q_{h}$ and total heat collected by the solar collector $Q_{\text {scrh }}$ can be expressed by the equations

$$
\begin{gathered}
Q_{h}=\int_{\text {chillerstartingtime }}^{\text {chillertopingtime }} \dot{m}_{f} C_{f}\left(T_{d, \text { in }}-T_{d, \text { out }}\right) d t \\
Q_{\text {scrh }}=\int_{\text {Sunrisetime }}^{\text {Sunsettime }} n A_{c r} I d t
\end{gathered}
$$

respectively. The simulation procedure is available elsewhere, in A lam et al [20].

The mean of the average maximum monthly radiation data of Dhaka for seven years (2003-2010) (Latitude $23^{\circ} 46^{\prime} \mathrm{N}$, Longitude $90^{\circ} 23^{\prime} \mathrm{E}$ ) has been used. Results are calculated based on solar data of Dhaka on the month of A pril. During A pril, in Dhaka, the sun rises at 5.5h and sets at $18.5 \mathrm{~h}$, where the maximum temperature is $34^{\circ} \mathrm{C}$ and minimum temperature is $24^{\circ} \mathrm{C}$. The average maximum solar radiation in this month is about 771 $\mathrm{W} / \mathrm{m}^{2}$. A sine function has been considered to simulate solar data. This equation is available in [25]. The tolerance for all the convergence criteria is $10^{-4}$.

The ambient temperature is calculated using the following equation:

$\mathrm{T}_{\mathrm{am}}=\left(\mathrm{T}_{\text {max }}+\mathrm{T}_{\text {min }}\right) / 2+\frac{\mathrm{T}_{\text {max }}-\mathrm{T}_{\min }}{2} * \operatorname{Sin}\left(\frac{\pi *(\text { Daytime }- \text { Sunrisetime }-\mathrm{i})}{\text { Daylength }}\right)$

where, i equals to the time difference between the maximum radiation and maximum temperature of the day.

\section{Result and discussions}

A conventional single stage basic adsorption chiller run by silica gel-water pair has been considered. Similar chillers with two adsorption beds have been first discussed by Dauss et al. [30]. An autonomous adsorption chiller run by solar heat, supported by a storage tank had been discussed by A lam et al. [25]. The performance of such a chiller has been compared with a chiller run by direct solar coupling by Rouf et al. [26]. Solar heat supported system performance is dependent on chiller configuration, collector number (also on available climatic conditions) and cycle time. For the climatic condition of Dhaka, 28 collectors $\left(48.16 \mathrm{~m}^{2}\right.$ collector area) are needed with 800 s cycle time to run this chiller with direct solar coupling for the base run conditions.W hen collector area is increased, the temperature of the heat transfer fluid (water) increases very rapidly and exceeds $100^{\circ} \mathrm{C}$ for the present chiller. It causes high pressure on the heat transfer pipe inside the collector as well as on the aluminium pipes used in the chiller. Thus, with $48.16 \mathrm{~m}^{2}$ collector area and 800 s cycle time, the adsorption bed temperature reaches $83^{\circ} \mathrm{C}$ while the collector temperature is $90.5^{\circ} \mathrm{C}$. With a collector area of $51.6 \mathrm{~m}^{2}$ (30 collectors) and 1000s cycle time, the collector temperature reaches $93.52^{\circ} \mathrm{C}$ which can increase the bed temperature to $92.07^{\circ} \mathrm{C}$ at the peak hours at steady state with a storage tank volume of $0.343 \mathrm{~m}^{3}$. If the tank volume is increased to 2.197 $\mathrm{m}^{3}$ (dimension: 1.3 meter) and holds $2187 \mathrm{~kg}$ water, it needs $75.68 \mathrm{~m}^{2}$ collector area (44 collectors) to increase 
collector temperature to $88.9^{\circ} \mathrm{C}$. It can raise adsorption bed temperature to $88.55^{\circ} \mathrm{C}$. It should be noted that for silica gel-water pair, driving temperature is around $80^{\circ} \mathrm{C}$. Hence, if a smaller number of collectors are considered, the collector temperature as well as the bed temperature will decrease. However, it affects the performance of the chiller.

Increase in the cycle time does not have much effect on the cooling capacity but it increases the operating time of the chiller. On the other hand, in the middle of the day, when solar radiation is at its maximum and the collector outlet temperature is at its highest, a smaller cycle time could be a better option. The maximum cooling capacity is depicted as being $11.5 \mathrm{~kW}$ for 61.92 $\mathrm{m}^{2}$ collector area (36 collectors) with a storage tank of volume $1 \mathrm{~m}^{3}$. Whereas, for direct solar coupling, maximum cooling capacity is $11.1 \mathrm{~kW}$ with the optimum collector area and cycle time discussed earlier. For an adsorption chiller assisted by heat storage, a huge amount of water in the storage tank needs to be heated. Therefore, a large collector area is needed. The collector area can be reduced if a smaller tank is utilized.

A s the system is at the steady state on the third day, for both cases, a comparative CA CC is depicted in Fig. 2. At the end of the day, as the tank water is still hot and this hot water is supplied to the desorber, it is working as the basic cycle after sunset. The system continues working until the temperature difference between the heat source (tank water) and heat sink (ambient temperature) is $25^{\circ} \mathrm{C}$. A this time, the heat supply from tank water, being used up gradually looses temperature. Hence, at this time, a longer cycle time is preferable. The chiller can function for a longer time after sunset if a larger tank is considered. Thus, when the volume of the tank is increased from 0.343 cubic meters to 1 cubic meter, it needs 6 more collectors $\left(10.32 \mathrm{~m}^{2}\right.$ additional collector area). But for the next 0.3 meter increase in the dimension, it needs to increase 8 more collectors (13.76 $\mathrm{m}^{2}$ additional collector area). Hence, a tank volume of 1 cubic meter produces optimum cooling capacity $11.5 \mathrm{~kW}$ and it works for almost 12.5 hours, namely from $8.5 \mathrm{~h}$ in

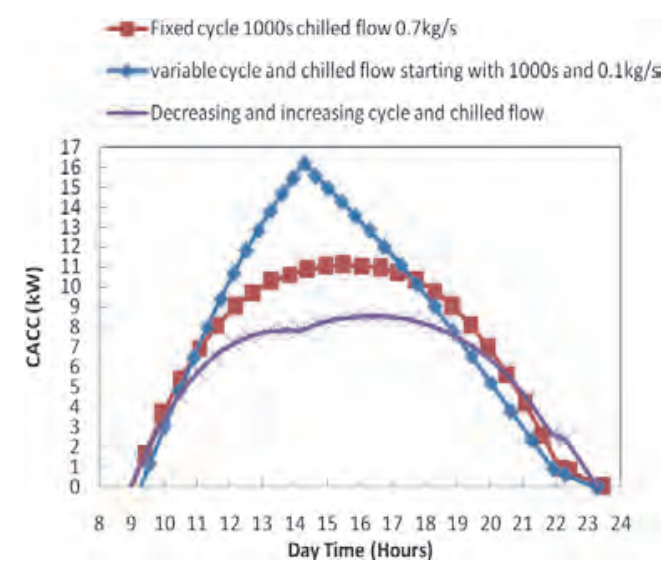

Fig 4. Comparative CA CC for different choice of cycle and Chilled flow for chiller with tank volume $2.197 \mathrm{~m}^{3}$
Table5. Energy distribution for different tank volume

\begin{tabular}{|l|l|l|l|}
\hline $\begin{array}{l}\text { Tank } \\
\text { volume } \\
\mathrm{m}^{3}\end{array}$ & $\begin{array}{l}\text { Total cooling } \\
\text { Produced } \\
\text { (MJ) }\end{array}$ & $\begin{array}{l}\text { Total Heat } \\
\text { used (MJ) }\end{array}$ & $\begin{array}{l}\text { Total Heat } \\
\text { collected } \\
\text { (MJ) }\end{array}$ \\
\hline $\mathrm{N} / \mathrm{A}$ & 305.9139152 & 647.0234632 & 646.6949381 \\
\hline 0.343 & 330.7191619 & 658.8672466 & 679.5850481 \\
\hline 1.0 & 365.0319832 & 722.1462433 & 785.7779722 \\
\hline 2.197 & 379.4378875 & 748.4155547 & 864.1006393 \\
\hline
\end{tabular}

the morning till 21.0h at night. However, with a tank of volume 2.197 cubic meters, cooling capacity is $11 \mathrm{~kW}$ and it functions for almost 14 hours, namely from $9.0 \mathrm{~h}$ in the morning till 23.0h, late at night.

For a larger storage tank, the system needs more heat to raise the temperature of the tank water. Hence, the solar heat collected through the additional collectors is mostly used up to heat the tank water rather than to be used in the chiller. The total energy collected and the total cooling production in one day for different cases is represented in Table 5.

That is, heat storage with solar heat driven cooling system produces $73.5 \mathrm{MJ}$ more cooling than a chiller with direct solar coupling. The installation of a storage tank enables the system to run for almost 4 more hours after sunset. It also enhances the overall cooling production by approximately $24 \%$. However, it needs to enhance $57 \%$ of solar collector area allocated to the change from direct solar coupling to the system with storage tank of volume $2.197 \mathrm{~m}^{3}$.

The bar diagram (Fig. 3.) demonstrates the total cooling energy produced compared with the total heat energy utilized for all the cases. It is observed that it uses comparatively less amount of heat energy to produce cooling energy in case of the system with storage tank compared with direct solar coupling and tank volume $2.197 \mathrm{~m}^{3}$. Which indicate energy leakage in case of system with direct solar coupling. On the other hand, in case of system with heat storage, residual heat collected

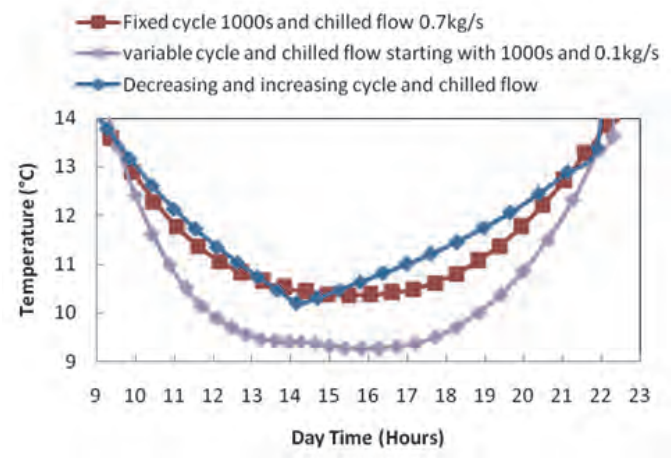

Fig. 5. Comparetive evaporator outlet for chiller with storage tank volume $2.197 \mathrm{~m}^{3}$ 
by the collector which is not used in the cooling production, is utilized to heat up the tank water.

A $n$ increased collector area and tank volume increases the working hour of the chiller, but the cooling capacity decreases. However, there remains the effect of the operating conditions on the performance of the chiller (Rouf et al. [22]). In the beginning and at the end of the day, heat input is very low, so it is preferable to use a longer cycle time to increase the temperature of the collector as well as the desorber. On the contrary, at midday, radiation is high and collector temperature is already above $80^{\circ} \mathrm{C}$. Hence, at this time, a shorter cycle is appropriate. A very high temperature does not help in enhancing the performance, but instead has an impact on the heat transfer fluid (water). Increased chilled flow increases the cooling capacity and the temperature of the evaporator out flow. In the intention to get a steady cooling effect for a longer time, controlled chilled water flow rate provides a better result. In this respect, a variable cycle time and variable chilled water supply to the evaporator throughout the chiller operating hours has been considered. Table 6 shows two different chosen variations of the two parameters respectively.

Figure 4 shows that the cooling capacity increases due to the variation in cycle time and chilled flow rate from $12.0 \mathrm{~h}$ to $18.5 \mathrm{~h}$. Figure 6 indicates a steady evaporator outl et temperature for choice i) (Fig. 5). The temperature is between $10^{\circ} \mathrm{C}$ to $9^{\circ} \mathrm{C}$ from $12.0 \mathrm{~h}$ to almost $18.0 \mathrm{~h}$. Due to these changes in the operating conditions, there are small variations in energy collection and cooling production. The adsorbent, once saturated or exhausted due to desorption, increased heat input or longer cycle time does not help in cooling production. Rather, when this cycle of adsorption-desorption is accelerated, better cooling capacity and lower cooling effect can be acclaimed. The choice of variable cycle time and chilled water flow rate for optimum performance is depicted in Fig. 6. Consequently, the system design should depend on how much cooling production and maximum cooling capacity is required. The increase in heat energy collection and cooling production is represented in Table 7.

A ton of refrigeration is $3.517 \mathrm{~kW}$ [31]. N ow, let one find out the number of units consumed per hour by a conventional 1.5 Ton A ir Conditioner. The indoor unit is constantly on, but the compressor doesn't run the whole time. It only starts when the indoor temperature begins to rise and stops once the required temperature is achieved. So, in an hour, the compressor runs only for about half the time. So, the total no. of units consumed per hour would be $[(1 \mathrm{~kW} \times 0.5 \mathrm{hrs})+(0.2 \mathrm{~kW} \times 1 \mathrm{hr})]=0.7 \mathrm{kWh}$ [32]. Now, one can multiply this factor with the number of hours the AC runs in a month. Suppose it runs for about 6 hours every day. Then the total units consumed would

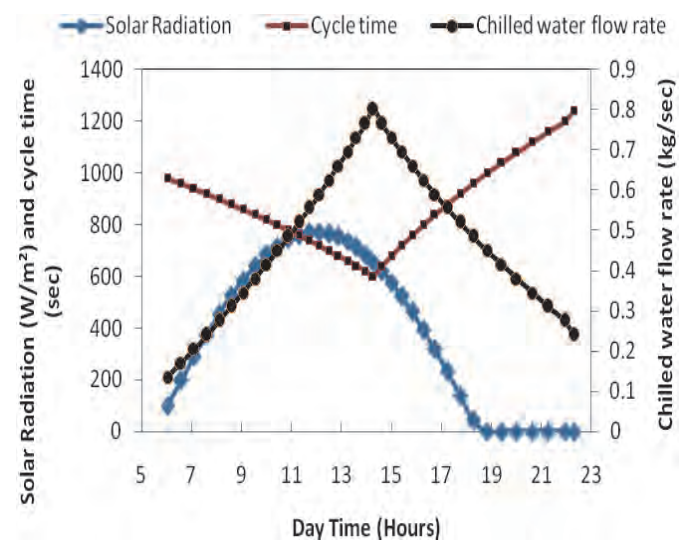

Fig. 6. Choice of variable cycle time and chilled water flow rate for optimum performance with storage tank volume $2.197 \mathrm{~m}^{3}$

Table6. Choice of operating conditions

\begin{tabular}{|c|c|c|}
\hline $\begin{array}{l}\text { Operating } \\
\text { parameter }\end{array}$ & $\begin{array}{l}\text { Sun rise hour till } \\
14.0 \mathrm{~h}\end{array}$ & $\begin{array}{l}\text { 14.0h till chiller } \\
\text { stop time }\end{array}$ \\
\hline Cycle time & $\begin{array}{l}\text { i) Starting with } \\
1000 \text { s decreasing } \\
\text { in every } \\
\text { consecutive cycle } \\
\text { at the rate of } \\
20 \text { s/cycle } \\
\text { ii) Starting with } \\
1000 \text { s decreasing } \\
\text { in every } \\
\text { consecutive cycle } \\
\text { at the rate of } \\
20 \text { s/cycle }\end{array}$ & $\begin{array}{l}\text { i)increasing in } \\
\text { every consecutive } \\
\text { cycle at the rate } \\
\text { of } 40 \text { s/cycle } \\
\text { ii) increasing in } \\
\text { every consecutive } \\
\text { cycle at the rate } \\
\text { of } 40 \mathrm{~s} / \mathrm{cycle}\end{array}$ \\
\hline $\begin{array}{l}\text { Chilled flow } \\
\text { rate }\end{array}$ & $\begin{array}{l}\text { i)Starting with } \\
0.1 \mathrm{~kg} / \mathrm{s} \text { increasing } \\
\text { in every } \\
\text { consecutive cycle } \\
\text { at the rate of } \\
0.035 \mathrm{~kg} / \mathrm{cycle} \\
\text { ii) Starting with } \\
1 \mathrm{~kg} / \mathrm{s} \text { decreasing } \\
\text { in every } \\
\text { consecutive cycle } \\
\text { at the rate of } \\
0.035 \mathrm{~kg} / \mathrm{cycle}\end{array}$ & $\begin{array}{l}\text { i)decreasing in } \\
\text { every consecutive } \\
\text { cycle at the rate } \\
\text { of } 0.035 \mathrm{~kg} / \mathrm{cycle} \\
\text { ii) increasing in } \\
\text { every consecutive } \\
\text { cycle at the rate } \\
\text { of } 0.035 \mathrm{~kg} / \mathrm{cycle}\end{array}$ \\
\hline
\end{tabular}


Table 7. Energy management tank volume $2.197 \mathrm{~m}^{3}$

\begin{tabular}{|l|c|c|c|}
\hline Case & $\begin{array}{l}\text { Total cooling } \\
\text { Produced } \\
\text { (MJ) }\end{array}$ & $\begin{array}{l}\text { Total Heat } \\
\text { used (MJ) }\end{array}$ & $\begin{array}{l}\text { Total Heat } \\
\text { collected } \\
\text { (MJ) }\end{array}$ \\
\hline $\begin{array}{l}\text { Cycle 1000s } \\
\text { chilled flow } \\
0.7 \mathrm{~kg} / \mathrm{s}\end{array}$ & 379.437 & 748.415 & 864.100 \\
\hline $\begin{array}{l}\text { Variable } \\
\text { cycle time } \\
\text { and chilled } \\
\text { flow rate }\end{array}$ & 411.101 & 756.922 & 880.969 \\
\hline
\end{tabular}

be $0.7 \times 180=126$ units per month. At current rates, on average 7.4 BDT per unit energy in Bangladesh, one would be paying $126 \times 7.4=932.4 \mathrm{BDT} /$ month. For the climatic condition of Bangladesh, two months- $M$ ay and June- are considered to be the full monsoon period. Therefore, if the solar adsorption chiller is considered to be running for 10 months a year, it could roughly save 9324 BDT/year only for 1RT space cooling purpose. Furthermore, it could guarantee a safe environment, and preserve electricity/fossil fuel. Moreover, it contributes in the preservation of food in rural areas.

\section{Conclusion}

A solar heat driven adsorption cooling system has been investigated for better energy utilization. In this regard, a direct solar coupling, a chiller with heat storage and a smart choice of operating conditions has been compared. In this study a conventional single stage, two bed, basic adsorption chiller has been considered which is driven by silica gel-water pair. Based on the above discussion following conclusions can be drawn;

i) When the chiller is connected with a storage tank of volume $2.197 \mathrm{~m}^{3}$, the overall cooling production is increased by approximately $24 \%$. However, it needs to enhance $57 \%$ of solar collector area compared with direct solar coupling.

ii) The maximum cooling capacity reported for storage tank of volume $1 \mathrm{~m}^{3}$ with cycle time $1000 \mathrm{sec}$ and chilled water flow rate $0.7 \mathrm{~kg} / \mathrm{sec}$ is $11.5 \mathrm{~kW}$.

iii) The cooling capacity can be increased to a maximum value of $16.1 \mathrm{~kW}$ for a storage tank of volume $2.197 \mathrm{~m}^{3}$, for which overall cooling production increases by $8 \% / 75.68 \mathrm{~m}^{2}$ collector area in one day, when variable cycle time and chilled flow rate is considered based on particular time of the day.

Performance of such a chiller, considered in this paper, can be improved by undertaking a backup heat source. There remain other options to be taken as backup, these comparisons will be discussed in the future.

\section{Nomenclature}

\begin{tabular}{|c|c|}
\hline A & A rea $\left(m^{2}\right)$ \\
\hline$C_{p}$ & specific heat $(\mathrm{J} / \mathrm{kgK})$ \\
\hline$C_{w, v}$ & specific heat of water vapor ( $/ \mathrm{kgK}$ ) \\
\hline 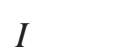 & solar radiation $\left(\mathrm{W} / \mathrm{m}^{2}\right)$ \\
\hline L & latent heat of vaporization ( / / kg ) \\
\hline$\dot{m}$ & mass flow rate $(\mathrm{kg} / \mathrm{s})$ \\
\hline$q$ & adsorption capacity $\left(\mathrm{kg} / \mathrm{kg}_{\mathrm{s}}\right)$ \\
\hline Q & energy \\
\hline Qst & heat of adsorption ( $/ \mathrm{kg}$ ) \\
\hline $\mathrm{t}$ & time (s) \\
\hline $\mathrm{T}$ & temperature $(\mathrm{K})$ \\
\hline U & heat transfer coefficient $\left(\mathrm{W} / \mathrm{m}^{2} \mathrm{~K}\right.$ ) \\
\hline Uloss & heat loss coefficient ( $\mathrm{W} / \mathrm{m}^{2} \mathrm{~K}$ ) \\
\hline Utloss & heat loss coefficient of tank $\left(\mathrm{W} / \mathrm{m}^{2} \mathrm{k}\right.$ \\
\hline$w$ & $M \operatorname{ass}(\mathrm{kg})$ \\
\hline
\end{tabular}

\section{Subscripts}

a

adsorber

am ambient

bed adsorbent bed

chill chilled water

con condenser

cp collector pipe

$\mathrm{cr} \quad$ collector

d desorber

eva evaporator

f heat transfer fluid (water)

h heat

l liquid

M metal

$r \quad$ refrigeration

$s \quad$ silica gel

Scrh solar heat consumed by collector

$t$ tube

tm tank metal

v vapor

w water

wt tank water

\section{References}

1) F. M eunier, Solid sorption heat powered cycles for cooling and heat pump applications, Applied Thermal Engineering, 18, 714-729 (1998).

2) K.C. Ng, Kyaw Thu, A. M yat, Numerical simulation of solar- assisted multi-effect distillation (SM ED) desalination systems, D esalination and Water Treatment, 51 (4), 1-12 (2012). 
3) S. M itra, K. Srinivasan, P. K umar, S. S. M urthy, P. Dutta, Solar driven adsorption desalination system, Energy Procedia, 49, 2261-2269 (2014).

4) S. M. Wakil, Kyaw Thu, B. B. Saha, A n emerging hybrid multi-effect adsorption desalination system, Evergreen: joint journal of Novel Carbon Resource Sciences \& G reen Asia Strategy, 1(2), 30-36 (2014).

5) K. Young-Deuk, Kyaw Thu, K. C. Ng, Evaluation and parametric optimization of the thermal performance and cost effectiveness of active- indirect solar hot water plants, Evergreen: joint journal of Novel Carbon Resource Sciences \& G reen Asia Strategy, 2(2), 50-60 (2015).

6) F. Meunier, Theoretical performance of solid adsorbent cascading cycles using Zeolite-water and active carbon-methanol pair; four cases studied, Heat Recovery CHP System, 6 (6), 491-498 (1986).

7) S. V. Shelton, J. W. Wepfer, D. J. M iles, Ramp wave analysis of the solid/vapor heat pump, ASME J. Energy Resource Technology, 112 69-78 (1990).

8) R. Z. Wang, Performance improvement of adsorption cooling by heat and mass recovery operation, International Journal of Refrigeration, 24, 602-611 (2001).

9) A. A kahira, K. C. A. Alam, Y. Hamamoto, A. A kisawa, T. Kashiwagi, Experimental investigation of mass recovery adsorption refrigeration cycle, International J ournal of Refrigeration, $\mathbf{2 8}, 565-572$ (2005).

10) H. T. Chua, K. C. Ng, A. Malek, T. Kashiwagi, A. A kisawa, B. B. Saha, Multi-bed regenerative adsorption chiller-improving the utilization of waste heat and reducing the chilled water outlet temperature fluctuation, International J ournal of Refrigeration, 24, 124-136 (2001).

11) B. B. Saha, E.C. B oelman, T. Kashiwagi, Computational analysis of an advanced adsorption refrigeration cycle, Energy, 20, 983-994 (1995).

12) B. B. Saha, K. C. A .A lam, A . A kisawa, T. Kashiwagi, K. C. N g., H. T. Chua H. T, Two-stage non-regenerative silica gel-water adsorption refrigeration cycle, Proc. ASM E Advanced Energy System Division, O rlando 65-69 (2000).

13) K. Uddin, I. I. El-Sharkawy,T. M iyazaki, B. B. Saha, S. K oyama,Thermodynamic analysis of adsorption cooling cycle using Ethanol surface treated M axsorb III pairs, Evergreen: joint journal of Novel Carbon Resource Sciences \& G reen Asia Strategy, $\mathbf{1}(1)$, 25-31 (2014).

14) A. Sakoda, A. M. Suzuki, Simultaneous transport of heat and adsorbate in closed type adsorption cooling system utilizing solar heat, J. Solar Energy Engineering, 108, 239-245 (1986).

15) A. P. F. L eite, M. Daguenet, Performance of a new solid adsorption ice maker with solar energy regeneration, Energy Conversion \& M anagement, 41 1625-1647 (2000).

16) A. Boubakri, A new conception of an adsorptive solar powered ice maker, Renewable Energy, 28, 831-842 (2003).

17) L. Yong, K. Sumathy, Modeling and simulation of a solar powered two bed adsorption air conditioning system, Energy Conversion and Management, 45, 2761-2775 (2004).

18) M. Clausse, K. C. A . A lam, F. M eunier, Residential air conditioning and heating by means of enhanced solar collectors coupled to an adsorption system, Solar Energy, 82(10), 885-892 (2008).

19) G. Zhang, D. C. Wang, Y. P. Han, W. Sun, Simulation of operating characteristics of the silica gel-water adsorption chiller powered by solar energy, Solar Energy, 85(7), 1469-1478 (2011).

20) K. C. A. Alam, B. B. Saha and A. A kisawa, A dsorption cooling driven by solar collector: a case study for Tokyo solar data, Applied Thermal Engineering, 50(2), 1603-1609 (2013).

21) R. A. Rouf, K. C. A. Alam, M. A. H. Khan, T. A shrafee, M. Anwer.,Solar Adsorption cooling: A case study on the climatic condition of Dhaka, J ournal of Computers, 8(5), 1101-1108 (2013).

22) R. A. Rouf, K. C. A . A lam, M. A. H. K han, Effect of operating conditions on the performance of adsorption solar cooling run by solar collectors, Procedia Engineering, 56, 607-612 (2013). 
23) F. M eunier, D. M ugnier, "La climatisation solaire", Dunod Ed., 'Competition between solar hot water and solar A/C', pp. 235-239 (2013).

24) M. A. H. A mmar, B. Benhaoua., M. Balghouthi., Simulation of tubular adsorber for adsorption refrigeration system powered by solar energy in sub-Sahara region of Algeria, Energy Conversion and $M$ anagement, 106, 31-40 (2015).

25) K. C. A. Alam, R. A. Rouf, B. B. Saha, M. A. H. K han, F. M eunier, A utonomous adsorption cooling driven by heat storage collected from solar heat, Heat Transfer Engineering,

DOI:10.1080/01457632.2015.1067045,

online: 16 N ov 2015.

http://dx.doi.org/10.1080/01457632.2015.1067045.

26) R. A. Rouf, K. C. A. Alam, M. A. H. Khan, B. B. Saha, F. Meunier, M. A. Alim, K. M. A. Kabir, A dvancement of solar adsorption cooling by means of heat storage, Procedia Engineering, 90, 649-656 (2014).

27) K. Young-Deuk, Kyaw Thu, H. K. Bhatia, C. S. B hatia, K. C. Ng, Thermal analysis and performance optimization of a solar hot water plant with economic evaluation, Solar Energy, 86 (5), 1378-1395 (2012).

28) B. B. Saha, E. C. B oelman, T. K ashiwagi, Computer simulation of a silica gel-water adsorption refrigeration cycle - the influence of operating conditions on cooling output and COP, ASHRAE Transactions, 101(2), 348-357 (1995).

29) B. B. Saha, S. K oyama, T. K ashiwagi, A. A kisawa, K. C. Ng. and H. T. Chua, Waste heat driven dual-mode, multi-stage, multi-bed regenerative adsorption system, Int. J . Refrigeration, 26, 749-757 (2003).

30) N. Douss, F. M eunier, L. M. Sun, Predictive model on experimental results for a two-adsorber solid adsorption heat pump, Industrial and Engineering Chemistry Research, 27(2), 310-316 (1988).

31) http://www. pow erknot.com/what-is-a-ton-of-refriger ation.html

32) http://www.quora.com/How-much-electricity-units-i s-used-by-1-5-ton-split-A C 